\title{
INVENTION OF PRODUCT AND COMMUNICATION IN TOURISM ENTERPRISES
}

\author{
Janka Beresecká \\ Slovak University of Agriculture in Nitra, Slovakia, e-mail: janka.beresecka@uniag.sk \\ Monika Hudáková* \\ Slovak University of Agriculture in Nitra, Slovakia, e-mail: monika.hudakova@uniag.sk \\ Veronika Hamadová \\ Constantine the Philosopher University in Nitra, Slovakia, e-mail: v.hamadova@gmail.com
}

Received September 2018; Accepted December 2018

\begin{abstract}
Purpose - The tourism sector is faced with the great challenges posed by globalization, technological development, shrinking geographical distances, faster transport options, etc. There is also a strong pressure on innovation in this area to expand and improve not only product but also communication policy. The aim of the paper is to highlight the importance of product innovation and to evaluate tourism communication and its transfer to practice, which results in the company's sustainability in a competitive market.

Design/methodology/approach - The goal of the contribution was met by two partial goals. The object of the survey was a travel agency with an important position on the Slovak market. The time period was the period of $2012-$ 2018. Several quantitative and qualitative processing methods were used in the thesis, namely group interview, questionnaire survey, Delphic method, Likert scale, comparative method. We worked with the three expert groups on the Delphi method. For the sake of comprehensive knowledge, the tourism market research was carried out by both supply and demand.

Findings - There is a change in foreign tourism products from last minute to first minute, to the preference of domestic holidays due to the negative effects of tourism from several areas, most political.

Research limitations/implications - The results of the phenomenon examined can be generalized marginally. Since the qualitative data would be appropriate to supplement basic economic data, which is sensitive to the legal form and ownership of the object under investigation. The investigated object operates in the private sphere and did not provide all the data that would assist in wider research and deeper understanding of the subject under consideration.

Practical implications - The results have indicated that targeted work with the structure and scope of tourism products, communication tools used by the enterprise can lead to sustainability, positive image creation or prestige.

Originality/Value - The results reported in the contribution are the results of field research, obtained and compared, with the relevance of the data being highlighted by identical unchanged entities operating this activity, established on a long-term basis in the tourism market.
\end{abstract}

Keywords: product in tourism, communication in tourism, levels of product.

Research type: research paper.

JEL classification: Z32

\footnotetext{
* Corresponding author.
} 


\section{Introduction}

A tourism sector is faced with the great challenges posed by globalization, technological development, shrinking geographical distances, faster transport options and so on. Increased international competition in tourism has set new rules on the global tourism market and sought new innovative, imaginative products and tourism brands that can help create a unique product offer. There is also a strong pressure on innovation in this area to expand and improve not only product but also communication policy. Thus, the aim of the paper is to highlight the importance of product innovation and to evaluate tourism communication and its transfer to practice.

\section{Theoretical background}

Innovation is perceived through gastronomic culture (Kontis and Skoultsos, 2018), innovations in product development and market diversification outside the peak tourist season (Connell, Page, Meyer, 2015), changes in understanding and creating conditions that result in a positive experience with internet markers (Morgan, Veloutsou, 2013, Alejziak, 2007), changes in perceptions of satisfaction, quality, performance and various other variables that are a good predictor of customer's intended loyalty (Geng-QingChi, Qu, 2008) women's leisure activities and preferring holiday experiences (ChiehChen, King, WenLee, 2018). This suggests that gender-based perspectives offer further prospects for better understanding of attitudes and behavior of tourists.

There is no consensual definition of a tourism product in the professional literature, but there is a general understanding that the present product must appeal to travelers seeking either business or leisure activities $(X u, 2010)$. We can understand it as a group of components that connect services and create a package to meet the needs of the consumer. In tourism, the product has an irreplaceable place as one of the most important tools in tourism marketing. Figure no. 1 we can see a tourism product model that is made up of several elements.
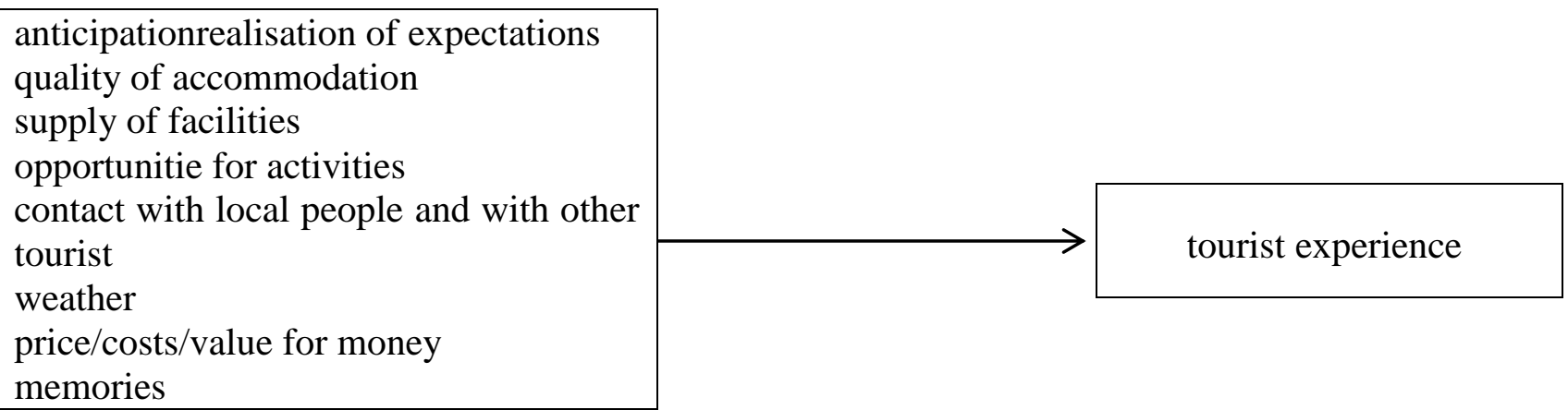

Source: processed in accordance with Pender, L., Sharpley, R., 2005

Figure 1. The total tourism experience 
It is made up of a set of activities, services and utilities that create a comprehensive tourist experience. In continuing to the original Middleton model (2009, In Palenčíková, 2015), the total tourism product is defined as "a package or set of tangible and intangible elements that is based on the activities performed at the target site. The package is perceived by the visitor as an overall experience and is available at a certain price "(Middleton, 2009, In Palenčíková, 2015, p. 11).

According to Burkheiser (1969) and Scheucha (1993), the product fulfills two tasks in terms of marketing. The first task is to feed the customer's needs with the features it has. The second task is that its sales become the centerpiece of the company's goals, even if the underlying goal of a business is profit, which is derived from total sales of products that sink customers' needs.

Authors Jefferson and Lickorish (In Seaton, Bennet, 1991, p. 113) define the product of tourism: "a set of physical product characteristics and characteristics of services provided together with symbolic associations that are expected to satisfy the customer's wishes and needs. Another view of the tourism product was taken by Reime and Hawkins (1979, p. 68), who consider the product of tourism to be a range of experience, consisting of experience with accommodation, natural and other resources, entertainment, transportation, catering, recreation and other activities. Cibáková (2007, p.141) has published that: "The product is something that can be put on the market for attention, acquisition or use and has the ability to satisfy the wishes or needs." The term tourism product is not easy to explain and define such as, for example, the automotive product industry. Tourism itself represents a specific sector of the economy, where the bulk of economic activities are realized at the target site (issues of production, employment, quality, etc.) in which they were created. Production and consumption are usually done in one place. Destination visitors should be able to choose from an adequate amount of products and should be directly involved in the product creation process they have purchased.

Marshall, Stuart, Solomon (2006) claim that the product of tourism also includes the design and packaging of goods, as well as its physical features and any associated services such as the import of goods. The authors of Rašovská and Ryglová (2017) include everything under the tourism product through which the destination in tourism is marketed and acquired by tourists and visitors, that is, all that the site offers to its inhabitants, visitors, businesses and potential investors, and what serves to satisfy them individual and collective needs. Perri (2015) claims that product development is influenced by the expectations of tourists who are currently more sophisticated and are looking for more individualized travel experiences, often defined as interest-based travel. Typical features of the tourism product are certain characteristics that distinguish it from other products on the market. It is a cluster of heterogeneous goods and services and the tourism product is not visible and can not be measured. Typical characteristics of tourism product Palenčiková (2015) considers immateriality and binding of the product to the destination, permeability, complexity and 
complementarity, substitutability, indivisibility of production and consumption. It also adds that production and consumption of the product must be harmonized not only in terms of time but also spatial.

Van Vliet (2012) relies on Kotler's concept of product levels. It has developed the concept of five levels of product (layers) that need to be thoroughly thought out when creating product strategies and when offered to individual customers (Figure 2). The goal of every tourism product is to provide both functional and psychological value to the customer. The bid side should take into account when creating the product that the product is sequentially arranged in levels. When each of the levels is designed correctly, it adds value to the customer.

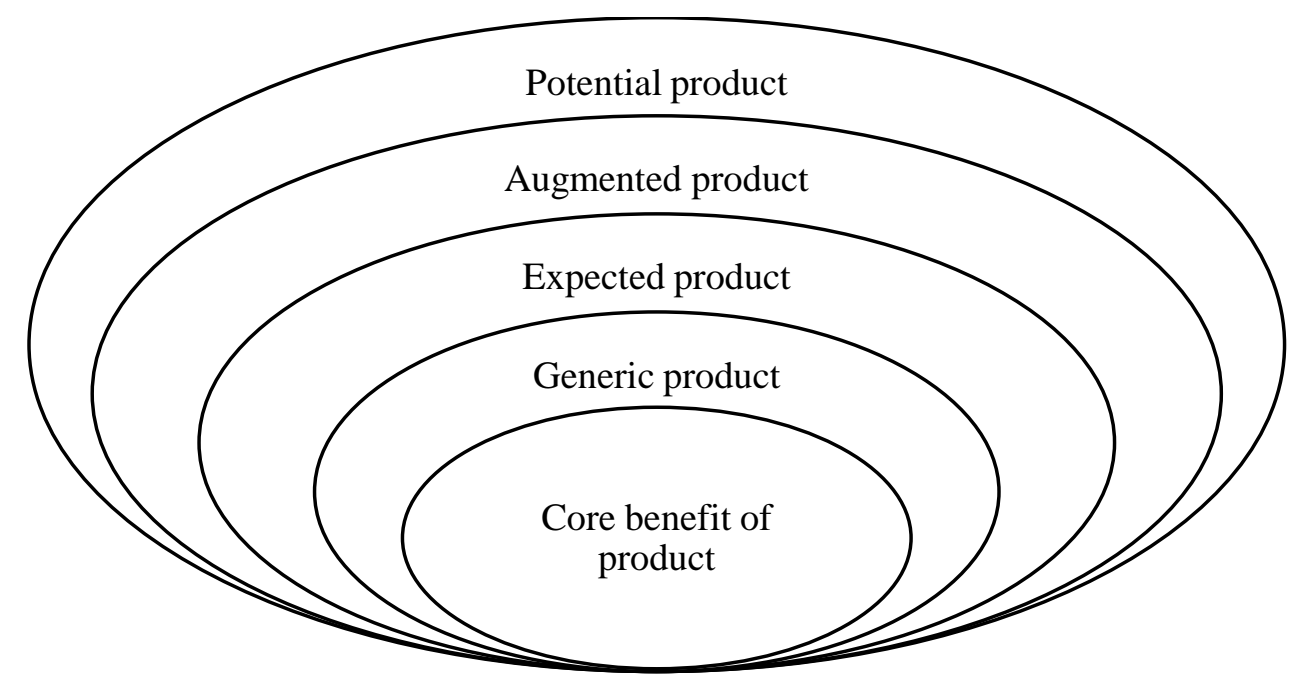

Source: processed in accordace with Van Vliet, 2012

Figure 2. Five product levels

1. Core product - the core benefit of the product to be the core of the product. Customers are not primarily looking for a product, but a tool to meet their needs or the equivalent of meeting tourism needs can be a set of services.

2. Generic product. If a producer sees the essential benefit the consumer is looking for, he needs to ensure that this benefit is provided to him. Van Vliet (2012) states that the basic benefits need to be transferred to the basic product so that the consumer can benefit from it and benefit from it.

3. Expected product according to Palenčiková (2015) is closely related to standardization of services. The customer has a number of alternatives to meet the needs, basing the purchasing decisions on the underlying assumptions, and ignoring those where it is assumed that expectations will not be met.

4. Augmented product may offer an offer that the customer did not expect very much, but it would surprise him. Above all, brand identity and image are here. The service provider offers this offer in order to differentiate itself from competition and to get a customer for repeated purchases. 
5. A potential product requires a high level of creativity on the supply side. The range of customers at this level can be narrowed as this service is very costly, which can cause a drop in purchasing power, but it is a challenge for the enterprise to find new approaches to satisfy customers (Kandampully, 2001).

Bel and the team (2014) say that new types of tourists will be emerging in the countryside, who will prefer the deeper use of the landscape from an environmental, cultural and architectural point of view. They will expect authentic, interactive and quality travel experiences focused on deep processing of a theme or destination. There will be a shift from the economy of services to the economy of experience. In the experience economy, tourists will look for quality experiences in which they will invest time and money. This is closely related to the changing relationship between hosts and guests.

One of the partial objectives of the product should be to promote it through the overall satisfaction of visitors and the system linking of all areas related to tourism (transport infrastructure, cultural and sports facilities, public facilities, etc.). Alternatively, to provide a combination of multiple services for tourists within a package, so called "pack" is often used in international tourism and is produced in a particular environment. International tourism is based on the maximum interconnection of destinations and services provided by providers in the given location. The center of attention is the creation and sale of a destination as a tourism product (Meszárošová, Z., Levický, M., 2017).

Changes also occur in the consumer behavior of tourists, which includes certain decisions, activities, ideas, or experiences, to meet the needs of consumers. The decision-making process is becoming much more routine, which at the moment rebuts the view of Hyde and Lawson (2003) who have found that tourist decisions include planned purchases. The choice of tourist destinations is related to the instrumental (external) and terminal (internal) values of consumers in tourism. There is a new research area that examines how expectant factors and pre-holiday attitudes and loyalty factors after the holidays affect motivation. Expectations have an important role to play in determining satisfaction, trust and other post-buying behavior (Zeithaml and Berry and Parasuraman, 1993 In Cohen et al., 2014). Lundberg (1971) has published a study on what motivates people to travel. He developed a package of 18 motivations that should influence travel. Crompton (1979) later identified nine motivations on the basis of research, of which seven were classified as "socio-psychological" and two as "cultural". Goeldner and Ritchie, 2003, classified the typology of tourism motives as discovering new geographic areas, interpersonal (joining and meeting new people), prestige such as self-esteem and self-activation (In Park, Yoon, 2009). The current communication system is generally diametrically different from the forms and communication strategies used twenty years ago when marketing communication was identified 
primarily with television advertising or sales support activities. Communication tools are combined and corporate know-how of each enterprise is mutually intertwined. In today's world, the struggle for customers has a crucial role to play.

According to Škarabelová (2006) marketing communication represents the means by which the company seeks to inform, convey and remind customers directly or indirectly. In essence, it represents the exchange of information about the product, service or organization between the source and the recipient of the report, aiming at mediating information and their content meaning to guide attitudes, expectations and ways of behaving in accordance with the specific goals of the organization.

Zamazalová (2009) considers that communication itself should not focus solely on addressing short-term goals (changing consumer preferences). The intent of marketing communication should be to manage long-term customer relationships throughout all stages of the purchase, including after consumption. In general, however, marketing communication is a major supportive starting point for companies to offer and influence the market environment (Jedlička, In Matúš, 2012).

However, current trends in marketing suggest that many marketing activities require far more intense communication with target groups. Classic marketing is not enough to ensure prosperity and competitiveness not only for companies but also for regions. The source of a unique competitive advantage is increasingly being sought in communication, in relationships with important target groups. It is the interdependence of all communication activities that lead to the creation of tailormade communication to individual target groups. Such naming is called integrated marketing communication in the literature (Přikrylová, Jahodová, 2010). Communicating visitors through the increasingly popular social network Foursquare opens up new opportunities for destinations and locations. Foursquare is mainly used as an application on mobile phones and is linked to geolocation services. (Śtefko et al., 2015). The changes also concern the formation of new types of tourists who expect far greater and more profitable use of the landscape in the context of environmental, cultural and architectural resources (Bel, 2018), are more open to new experiences, the growing challenge of participating in the local lifestyle (Salvatore, Chiodo, Fantini, 2018), there will be a synergy between the visitor and the tourism service provider (Saxena, 2016). Changes will be based on knowledge. Silent knowledge that we can achieve on the basis of direct experience and procedural, based on official education and training programs for tourism enterprises (Yin and Jahanshahi, 2018). The combination of knowledge, perception, creativity and accidental occurrence constantly identifies the opportunities for the emergence of new tourism products (Russell and Faulkner, 2004) for an overall experience that covers the entire complex of aspects and product components, including attitudes and expectations (Ghadban et al. 2017). 


\section{Objective, material and methodology of the study}

The aim of the paper was to evaluate the importance of product innovations and the communication of tourism and their transfer into practice, which results in the company's sustainability in a competitive market. We fulfilled the stated goal by realizing:

- analysis of product development, composition and comparison,

- analysis of the development, composition and comparison of the various travel agency communication tools in the 2012-2018 timeframe.In order to obtain a comprehensive view of the problem solved, we used secondary and primary resources, quantitative and qualitative methods of processing, random and deliberate selection of the research sample, detailed in Figure 3.

The field research results are relevant, not generalized, as the current travel law is not specified by the travel agency.

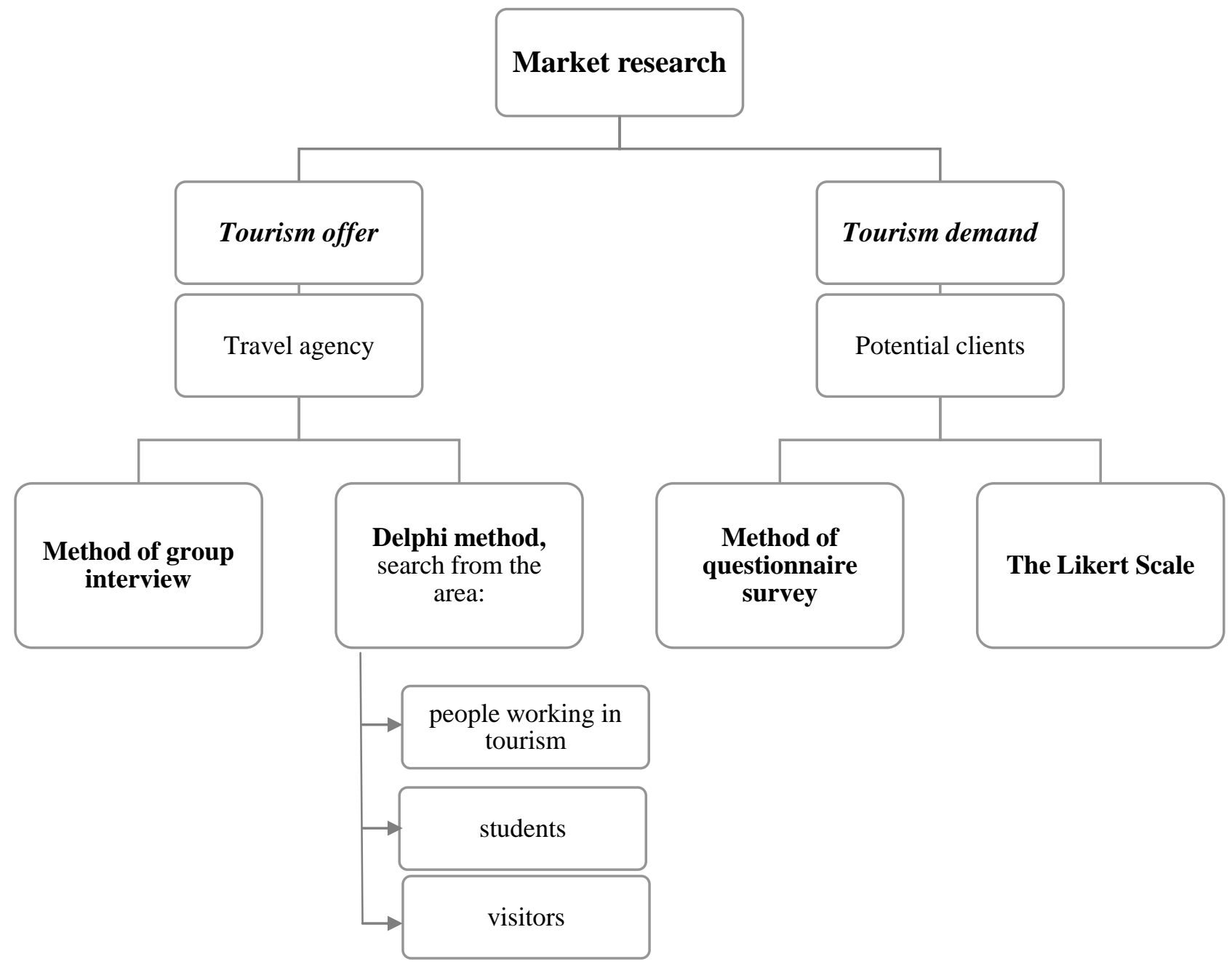

Source: own processing

Figure 3. Graphic processing of the scope of field research and processing methods

Structurally, we surveyed the future trends of tourism development with the online sales and call center manager of a selected travel agency (no consent was given to its specific specification). 
The interview consisted of 9 pre-prepared questions, including a question about what products and destinations customers are interested in and what they expect from a travel agency offer in the near future.

In the contribution, we also used the prognostic Delphi method, which was aimed at achieving convergence of opinion and a certain consensus in looking at the issue between experts and experts. The questions focused on the current state of tourism in Slovakia, but also abroad, what trends can be expected from the point of view of the operators presenting the offer, but also of the tourism participants representing the demand. We created 3 target groups, including tourism experts, students and tourists. The Delphic method was conducted with a survey approach, a questionnaire was created, the questioning was two-way. By using the Delphi method we have gained consensus of experts to look at the future of tourism development.

In order to identify future trends in the development of tourism by demand, we used the questionnaire survey method for potential clients, where we focused on consumer buying behavior. In pre-sale behavior, we investigated what constitutes the main motivation of clients' holidays (motivators), we followed the attitudes of clients in ponderous behavior. The questionnaire consisted of 21 closed or open questions, distributed over the internet and 69 respondents. Likert scale, which usually examines the attitude, satisfaction, or experience of a respondent with a particular subject, has been used in the work. The purpose of this method is to ensure that the range includes a wide range of possible views and ideas.

\section{Results and discussion}

The status of tourism in Slovakia is accompanied and influenced by several changes. Tourists are more sophisticated, more experienced, expecting high standard tourism services to provide them with satisfaction and experience. The changes also affect the activities of individual tourism actors, including travel agencies.

The travel agency that has been the subject of research has maintained its leading position in the travel agency market in Slovakia since its inception. As part of its activities, it is constantly engaged in passive and active tourism and other complementary activities. The product of travel agency itself makes stays by sea, stays in Slovakia, sightseeing tours, cruises, wellness, exotic stays and tours, mountain stays and EXCLUSIVE stays.

The travel agency has changed the structure and range of products compared to 2012 (Table 1). She expanded her offer for sightseeing tours, added cruise tours, and knew exotics. She added her offer to wellness stays, where specifically Ayurveda and modern yoga were added. 
Table 1. Comparison of the products offered abroad by the travel agency in 2012 and 2018

\begin{tabular}{|c|c|c|c|c|}
\hline & Proc & offered in 2012 & Produ & cts offered in 2018 \\
\hline & stays & & holiday at the sea & \\
\hline & educationals trips & & "we know the world" & $\begin{array}{l}\text { cruise liner, } \\
\text { cruises along the Danube, } \\
\text { "we know exotics" }\end{array}$ \\
\hline & wellness & & wellness & $\begin{array}{l}\text { ayurveda, } \\
\text { yoga by the sea }\end{array}$ \\
\hline & mountains and lakes & & skiing and mountains & \\
\hline & exotics & $\begin{array}{l}\text { holidays by the sea } \\
\text { educational trips } \\
\text { cruise ship } \\
\text { special tours }\end{array}$ & exotics & \begin{tabular}{|l} 
holidays by the sea \\
"we know exotics" \\
sightseeing tours
\end{tabular} \\
\hline$\frac{\sigma}{0}$ & & & family & \\
\hline$I$ & skiing & & & \\
\hline & cruise & $\begin{array}{l}\text { cruises } \\
\text { cruises with a slovak } \\
\text { guide }\end{array}$ & cruise & $\begin{array}{l}\text { cruise COSTA } \\
\text { MSC cruise } \\
\text { cruises with a slovak guide }\end{array}$ \\
\hline & activities & $\begin{array}{l}\text { waterparks } \\
\text { weekends for children, } \\
\text { agrotourism } \\
\text { cycling } \\
\text { hiking } \\
\text { golf } \\
\text { gourmet experiences } \\
\text { Planet fun, } \\
\text { wellness }\end{array}$ & activities & \begin{tabular}{|l} 
waterparks \\
weekends for children \\
agrotourism \\
cycling \\
hiking \\
golf \\
gourmet experiences \\
Planet fun \\
wellness \\
sports academy
\end{tabular} \\
\hline & others & $\begin{array}{c}\text { business service } \\
\text { gift cards } \\
\text { tickets } \\
\text { commission } \\
\text { parking in Vienna } \\
\text { sales on installments } \\
\text { rental of buses } \\
\text { german railway } \\
\text { ticket sales }\end{array}$ & others & $\begin{array}{l}\text { business service } \\
\text { gift cards } \\
\text { commission } \\
\text { parking in Vienna } \\
\text { parking in Bratislava } \\
\text { rental of buses } \\
\text { ticket sales } \\
\text { incentrant tourism }\end{array}$ \\
\hline
\end{tabular}

Source: own processing and processed in accordance with Klinga, M., 2012

As the travel agency is also developing in the domestic environment, we have expanded the research results and compacted it in Table 2. 
Table 2. Comparison of the products offered in Slovakia to the travel agency in 2012 and 2018

\begin{tabular}{|c|c|c|c|c|}
\hline \multirow{9}{*}{ 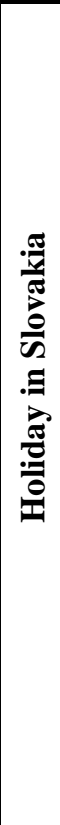 } & \multicolumn{2}{|c|}{ Products offered in 2012} & \multicolumn{2}{|c|}{ Products offered in 2018} \\
\hline & cottage & & & \\
\hline & wellness & & wellness & \\
\hline & $\begin{array}{l}\text { mountains and } \\
\text { lakes }\end{array}$ & & & \\
\hline & skiing & & skiing and mountains & \\
\hline & & & skiing & \\
\hline & & & educational trip & \\
\hline & activities & $\begin{array}{l}\text { wellness } \\
\text { weekends for children } \\
\text { agrotourism } \\
\text { for seniors }\end{array}$ & activities & $\begin{array}{l}\text { yoga } \\
\text { golf } \\
\text { wellness } \\
\text { cycling } \\
\text { agrotourism }\end{array}$ \\
\hline & others & $\begin{array}{l}\text { gift cards } \\
\text { commission } \\
\text { sales on installments } \\
\text { rental of buses }\end{array}$ & others & $\begin{array}{l}\text { gift cards } \\
\text { commission } \\
\text { rental of buses } \\
\text { thermal swimming pools } \\
\text { incentrant tourism }\end{array}$ \\
\hline
\end{tabular}

Source: own processing and processed in accordance with Klinga, M., 2012

From Tab. 2 shows that the travel agency also experienced changes in both domestic and foreign products compared to 2012. First of all, there is a change in the way products are broken down and the range of products is expanded to include sightseeing tours within Slovakia. The activities organized by the travel agency both in foreign (Table 1) and domestic (Table 2) tours are almost unchanged. It continues to provide many opportunities for active leisure time spending. The desired and appreciated activity is to include a sports academy in the services offered. Within this service, the teaching of children of various desirable and popular sports is taking place.

The surveyed entity also provides the requested service, which it has identified as "supplementary" in its portfolio. These include corporate service, sale of gift vouchers, sales commissions and much more. The travel agency also uses the organization of incental tourism, incentive programs for your best employees that can be combined with work meetings, training, presentations, participation in an exhibition or professional excursion. For the employees of the company, this represents an experience that remains unheard of in such an unusual way and the organization of the motivational journey is more effective than a permanent increase in salary.

In the past, the travel agency operated ticket sales through Ticketportal, and this service is now canceled. Also deutsche Bahn was canceled. Significant change has also been affected by discounts provided by the travel agency. In 2012, there were senior, student and ISIC discounts. At present, neither one of these discounts will offer a travel agency. The travel agency offers loyalty promises for employees of individual companies of national or supranational character.

The product being sold by the investigated entity is made through its own network of sales outlets. Tours will reach the client with a personal visit of individual branches, which are 46 all over 
Slovakia and also through the headquarters, which also serves as a sales function in addition to the management function. Another way of selling the product is to sell through a network of affiliate vendors of travel agent products. One of the options is also sales through online sales.

Travel Agency considers marketing communication to be one of the most important and most basic ways of addressing customers, acquainting them with the products and services they offer. The basic communication, presentation and promotional tool of the travel agency is the catalog. In order to fulfill its functions in relation to customers, it is important to pay reasonable attention to its creation and distribution. Every year the travel agency publishes a number of tour catalogs for the current season through which it seeks to reach out to the general public. The catalog offers basic information about the country, the destination of the stay, but also the description of the accommodation facilities. The catalog also includes a pricelist. It also uses other communication mix tools. Through the individual marketing communication tool, he pays great attention to how he understands how good and engaging advertising can help the overall positive perception of the business. The promotional policy, figure 4 of the travel agency, is well thought out, elaborate, creative and precise, which ultimately reflects on the position on the Slovak market where it holds one of the leading positions.

The results suggest that the subject under consideration places sufficient attention on each marketing support tool. In practice, communication support is a combination of its specific tools, which must be chosen in such a way as to achieve a strategic goal with the desired economic outcome of the business. The travel agency is constantly trying to improve and improve its services through various marketing activities and tools. He is fully aware that changes in communication policy are also necessary and desirable.

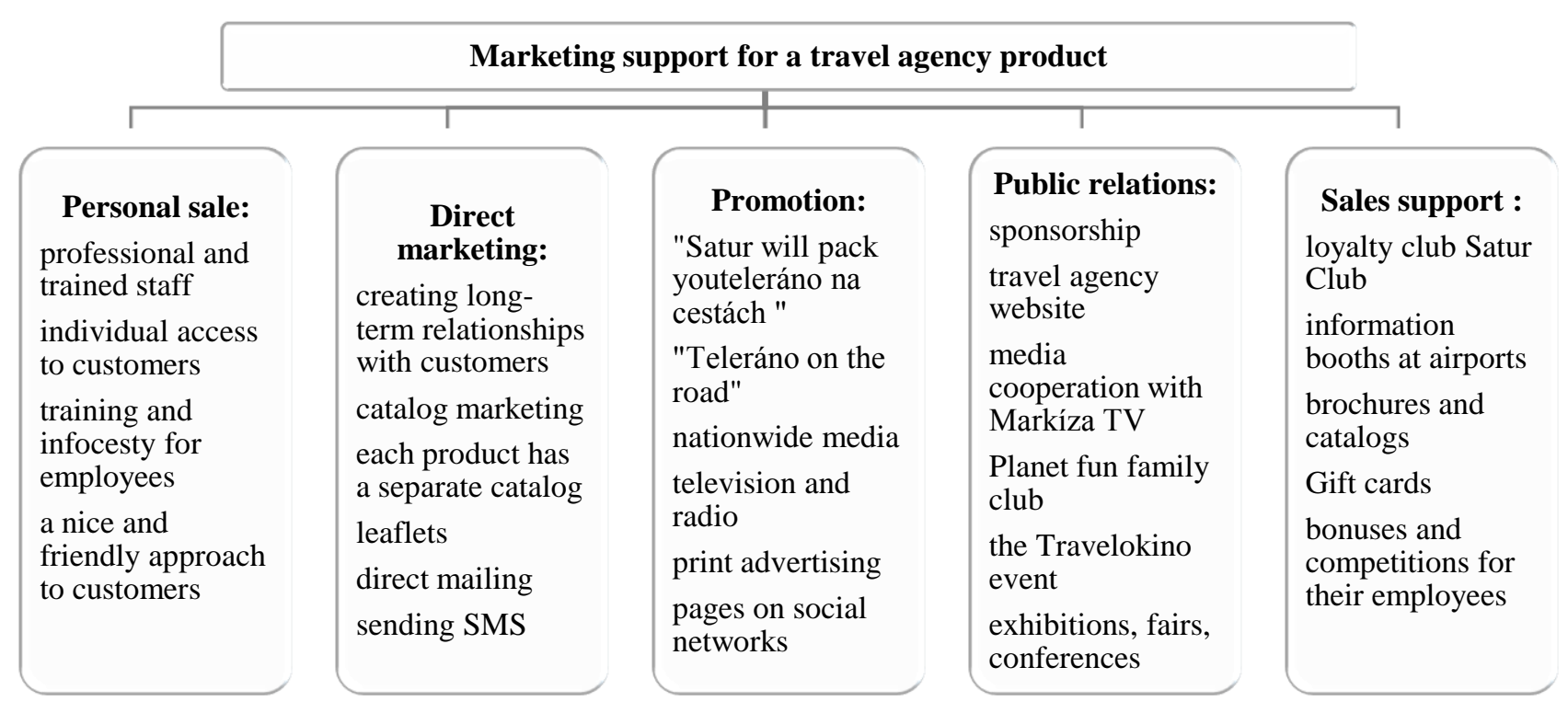

Source: own processing, 2018

\section{Figure 4. Graphic processing of marketing support for a travel agency product}


The development and analysis of these changes is provided in Table 3.

Table 3. Comparison of marketing tools in 2013 - 2018

\begin{tabular}{|c|c|}
\hline \multicolumn{2}{|c|}{ Promotion } \\
\hline 2013 & 2018 \\
\hline $\begin{array}{l}\text { TV show sponsorship (Modré z neba) } \\
\text { presentation of services in national television } \\
\text { nationwide and regional radios } \\
\text { own website } \\
\text { advertising on web servers - banners } \\
\text { presentation of services on social networks } \\
\text { (Facebook, Twitter) } \\
\text { advertising in newspapers, weeklies and weeklies }\end{array}$ & $\begin{array}{l}\text { presentation on TV Markíza, Joj and RTVS } \\
\text { Expres and Europe } 2 \text { radio } \\
\text { "hidden" advertising - production and distribution of } \\
\text { a wide range of promotional items for their business } \\
\text { partners and customers } \\
\text { magazines and diaries Emma, Forbes, Sme ženy, } \\
\text { Health, MIAU, Plus } 7 \text { days, Brejk } \\
\text { banner ads on many websites }\end{array}$ \\
\hline 2013 & 2018 \\
\hline $\begin{array}{l}\text { advertising space (citylight showcases, billboards, } \\
\text { posters) }\end{array}$ & $\begin{array}{l}\text { the headline "Satur keeps you packed" for a } \\
\text { traditionally good holiday } \\
\text { "Traffic on the Road" }\end{array}$ \\
\hline \multicolumn{2}{|r|}{ Sales support } \\
\hline 2013 & 2018 \\
\hline $\begin{array}{l}\text { catalogs } \\
\text { leaflets at the point of sale about current offers } \\
\text { newsletter - offers via e-mail } \\
\text { promotional items } \\
\text { fairs, exhibitions, events } \\
\text { loyalty cards } \\
\text { care of permanent customers } \\
\text { competitions - company presentation } \\
\text { gifts }\end{array}$ & $\begin{array}{l}\text { catalogs } \\
\text { loyalty Club Satur Club } \\
\text { information booths at airports } \\
\text { gift vouchers, hire purchase } \\
\text { fan page on social network Facebook and Instagram } \\
\text { discounts, vouchers } \\
\text { participation in fairs } \\
\text { sales promotion for business staff (bonuses, } \\
\text { competitions ...) } \\
\text { flexible holidays }\end{array}$ \\
\hline \multicolumn{2}{|c|}{ Public relations } \\
\hline 2013 & 2018 \\
\hline $\begin{array}{l}\text { creating long-term partnerships with journalists } \\
\text { presenting the company in accessible media (media } \\
\text { relatinos) } \\
\text { working with opinion leaders (most frequently } \\
\text { known media) } \\
\text { sponsoring the show "Modré z neba" } \\
\text { public responses to tourism crises on their own } \\
\text { website } \\
\text { publish articles in magazines to publish customer } \\
\text { feedback } \\
\text { events such as "Weekend for the Whole Family", } \\
\text { "Traveler Summer Cinema" and "Saturday" }\end{array}$ & $\begin{array}{l}\text { publishing articles in the mentioned magazines } \\
\text { own website } \\
\text { sponsoring } \\
\text { publication of annual reports - media cooperation } \\
\text { with television } \\
\text { the Planet Fun Family Club } \\
\text { organizing events - Cestokino, Cestokino Festival } \\
\text { attending conferences, seminars, exhibitions } \\
\text { project „HÝB SA“ Slovakia }\end{array}$ \\
\hline \multicolumn{2}{|c|}{ Direct marketing } \\
\hline 2013 & 2018 \\
\hline $\begin{array}{l}\text { catalog sales } \\
\text { online booking system for customers with current } \\
\text { prices and discounts } \\
\text { TOP database and VIP clients }\end{array}$ & $\begin{array}{l}\text { catalog sales } \\
\text { information leaflets } \\
\text { seasonal offers } \\
\text { direct mailing and SMS sending }\end{array}$ \\
\hline \multicolumn{2}{|c|}{ Personal sales } \\
\hline 2013 & 2018 \\
\hline $\begin{array}{l}\text { oral presentation of products to prospective } \\
\text { customers at individual locations } \\
\text { providing advice directly on sale or by telephone }\end{array}$ & $\begin{array}{l}\text { Individual access to individual customers } \\
\text { training focused on the targeted action of its } \\
\text { customers } \\
\text { training on sales standards that retailers teach as a } \\
\text { service to offer }\end{array}$ \\
\hline
\end{tabular}

Source: own processing and processed in accordance with Jurková, 2013 
After an in-depth review of the theoretical backgrounds on the subject, as well as the results of field research on supply and demand, using the multiple qualitative and quantitative methods, we reached the conclusions outlined in Table 4.

Table 4. Summarizing results of field research

\begin{tabular}{|c|c|c|}
\hline \multicolumn{2}{|c|}{ Tourism offer } & \multirow{2}{*}{$\begin{array}{c}\text { Tourism demand } \\
\text { Questionnaire survey } \\
\end{array}$} \\
\hline Structured interview & Delphi method & \\
\hline $\begin{array}{l}\text { impacts on consumer behaviour } \\
\text { and decision-making have climatic } \\
\text { conditions }\end{array}$ & $\begin{array}{l}\text { compared to Western countries, } \\
\text { tourism in Slovakia is less } \\
\text { developed } \rightarrow \text { not aware of the } \\
\text { benefits associated with tourism in } \\
\text { the domestic population }\end{array}$ & $\begin{array}{l}\text { the offer of a travel agency from } \\
\text { the respondents' perspective is } \\
\text { attractive and interesting }\end{array}$ \\
\hline $\begin{array}{l}\text { retreat of preferences buying trips } \\
\text { last minute }\end{array}$ & $\begin{array}{l}\text { the low rate of tourism promotion } \\
\text { in Slovakia }\end{array}$ & $\begin{array}{l}\text { the travel agency has a } \\
\text { sophisticated and thoughtful } \\
\text { marketing communication with its } \\
\text { clients }\end{array}$ \\
\hline $\begin{array}{l}\text { past }=\text { last minute, presence }= \\
\text { first minute }\end{array}$ & $\begin{array}{l}\text { the focus of tourists to explore the } \\
\text { country, its culture, how to relax at } \\
\text { the sea as it has been so far }\end{array}$ & $\begin{array}{l}\text { most popular type of holiday is } \\
\text { still a holiday at sea }\end{array}$ \\
\hline $\begin{array}{l}\text { client care, individual approach to } \\
\text { the client }\end{array}$ & demand for better services & $\begin{array}{l}\text { tourists would welcome less } \\
\text { expensive tours }\end{array}$ \\
\hline $\begin{array}{l}\text { the travel agency has not recorded } \\
\text { a significant increase or decrease } \\
\text { in clients over the last few years, } \\
\text { due to stable level of clientele } \\
\text { travelling with the given travel } \\
\text { agency several times a year }\end{array}$ & $\begin{array}{l}\text { the growth of rural tourism and the } \\
\text { demand for regional products }\end{array}$ & $\begin{array}{l}\text { internet and reviews from the } \\
\text { acquaintances belong to the most } \\
\text { used marketing tools in the } \\
\text { presence }\end{array}$ \\
\hline $\begin{array}{l}\text { an increase in the purchase of } \\
\text { tours online }\end{array}$ & $\begin{array}{l}\text { tourism in future will affect } \\
\text { modern ICT technologies }\end{array}$ & $\begin{array}{l}\text { up to } 88 \% \text { chose to spend holidays } \\
\text { abroad }\end{array}$ \\
\hline $\begin{array}{l}\text { the increased interest of seniors in } \\
\text { participation in tourism }\end{array}$ & $\begin{array}{l}\text { there will be growing interest in } \\
\text { travelling by seniors }\end{array}$ & $\begin{array}{l}\text { most of the respondents used the } \\
\text { services of the travel agency in the } \\
\text { past and were satisfied }\end{array}$ \\
\hline \multirow[t]{3}{*}{$\begin{array}{l}\text { the impact of terrorist attacks on } \\
\text { the client's decision to buy a trip }\end{array}$} & $\begin{array}{l}\text { when selecting a holiday abroad, } \\
\text { clients will choose destinations } \\
\text { where there is no danger and } \\
\text { political unrest }\end{array}$ & $\begin{array}{l}\text { tourists are no longer enjoying } \\
\text { classic vacations, but they want to } \\
\text { enjoy their experiences and } \\
\text { adventure }\end{array}$ \\
\hline & $\begin{array}{l}\text { domestic holidays will prevail } \\
\text { over foreign }\end{array}$ & absence of adrenaline tours \\
\hline & $\begin{array}{l}\text { immigration of large numbers of } \\
\text { people into European countries }\end{array}$ & \\
\hline
\end{tabular}

Source: own processing, 2018

The results in Table 4 are the selection of outputs from managed interviews. From which follows: "When buying a product, there is a trend in the fact that, if 5 years ago most of the clients were buying last minute holidays, this trend is currently turning and dominating the first minute tours. The customer will pay more in the end because the first minute offers higher discounts than the last minute. "To the question: What obstacles do you see in the development of tourism?

Tourism experts: ,... the biggest obstacle to the development of tourism around the world, we see in the increasing number of terrorist attacks, which also shows imminent danger in the country. For other factors, experts have identified the immigration of a large number of people 
from a completely different culture into the visited resorts and the adverse conditions for the entry of the tourists into the country. "

Students: ,... the political situation in the country. It is logical that no one wants to go to vacation in countries where riots are being ruled (terrorism, crime, war, civil war ...) ".

Tourism Participants: „... it is possible that tourism will fall in the future due to foreign hazards due to different hazards (terrorism) and people will prefer holidays in their territory. Definitely a man, with his family and children, chooses a destination that is safe for his whole family and will not expose the situation. Other disagreements included religious disagreements, which are closely related to the terrorist situation. "

\section{Conclusion}

The results of extensive research suggest that it is necessary to innovate the product at all stages of development and its forms of visibility, sales through marketing communications, and for market sustainability. During the period under review, the travel agency experienced developmental dynamics not only in the range of products offered, but also enriched its offer of activities that brought about a change in lifestyle, the sophistication of travelers, which is also reflected in numbers. To make the product visible, it uses 8 thematically cataloged catalogs, 23x has received prestigious awards, has 46 branches within the Slovak Republic and more than 90,000. of satisfied clients a year. The research results obtained by the Delphic method indicate that the target group of $50+$ travelers has been expanding, the interest in domestic holidays is growing. One reason is concerns about the negative effects of foreign tourism.

\section{References}

Alejziak, W. (2007) Megatrendy a výzvy rozvoja politiky národního a medzinárodného cestovného ruchu. In Ekonomická revue, Vol.. 40, No. 1: 3-20. ISSN 0139-8660.

Bel, F., Lacroix, A., Lyser, S., Rambonilaza, T., Turpin, N., (2015) Domestic demand for tourism in rural areas: insights from summer stays in three French regions.In Tourism Management, vol. 46, pp. 562-570. ISSN 0261-5177. DOI <https://doi.org/10.1016/j.tourman.2014.07.020>.

Bel, F. et al. Domestic demand for tourism in rural areas: Insights from summer stays in three French. [online]. [cit. 2018-11-27]. DOI: <regionshttps://mpra.ub.uni-muenchen.de/66255/1/MPRA_paper_66255.pdf〉.

Burkheiser, U. (1969) Das Produkt als Bestimmungsfaktor derAbsatzpolitik: Ein Versuch zur Weiterentwicklung der Absatztheorie. Dizertačná práca.Frankfurt am Main: Verlag Harri Deutsch.

Cibáková, V., Bartáková, G. (2007) Základy marketingu. Bratislava: IURA EDITION. Edícia EKONÓMIA, 224 s. ISBN 978-80-8078-156-9.

Cohen, S., et al., (2013) Consumer behaviour in tourism: Concepts, influences and opportunities. In Current Issues in Tourism, vol. 17, no.10, pp. 872-909. ISSN 1368-3500. DOI <10.1080/13683500.2013.850064>.

Connell, J.S., Page, J., Meyer, D. (2015) Visitor attractions and events: Responding to seasonality. In Tourism Management. Vol. 46, pages 283- 298. DOI: 〈https://doi.org/10.1016/j.tourman.2014.06.013>. 
Geng-QingChi, Ch., Qu, H. (2007) Examining the structural relationships of destination image, tourist satisfaction and destination loyalty. In Tourism Management, Vol. 29, Is. 4: 624-636. DOI: <https://doi.org/10.1016/j.tourman.2007.06.007>.

Ghabdan, S. - Shames, M., Arrage, J.A. - Fayyad, A.A. (2017) Rural tourism in Lebanon: what does the market reveal?

Hyde, K.F, Lawson, R., (2003) The Nature of Independent Travel. In Journal of travel Research, vol. 42, pp.13-23.

ChienChen, Y., King, B., WenLee, H. (2018) Experiencing the destination brand: Behavioral intentions of arts festival tourists. In: Journal of Destination Marketing \& Management, Vol, 10, P. 61-67. DOI: <https://doi.org/10.1016/j.jdmm.2018.06.004>.

Jurková V. (2013) Marketingová komunikácia a komunikačný mix vybraného podniku: bakalárska práca. Bratislava: Ekonomická univerzita, $76 \mathrm{~s}$.

,Kandampully, J. et al. (2001) Service Quality Management in Hospitality, Tourism, and Leisure. New York: Haworth Press. 340 p. ISBN 0-7890-0726-6.

Klinga, M. (2012) Spokojnost’ zákazníkov so službami vybraných cestovných kancelárií: diplomová práca. Nitra: SPU, $80 \mathrm{~s}$.

Kontis, A.P., Skoultsos, S. (2018) Enhancing Hospitality Services Through the Engagement of Visitors in Local Gastronomy Experiences: A Marketing Perspective from the Supply-Side. In: Katsoni V., Velander K. (eds) Innovative Approaches to Tourism and Leisure. Springer Proceedings in Business and Economics. Springer, Cham. [online] [accessed 6 November 2018]. Online ISBN 978-3-319-67603-6. DOI: <https://doi.org/10.1007/9783-319-67603-6_26>.

Marshall, G. W., Solomon, M. R., Stuart, E. W. (2006) Marketing očima světových marketing manažerů. Brno: Computer Press, a.s., 572 s. ISBN 80-251-1273-X.

Matúš, J. (2012) Interakcia marketingu vzdelávania a znalostnej spoločnosti. In: Megatrendy a média. Zborník $\mathrm{z}$ vedeckej konferencie. Trnava: Univerzita Cyrila a Metoda, $49 \mathrm{~s}$.

Meszárošová, Z., Levický, M. (2017). Tourism as a means to support the development of Euro-regions in Slovakia in Scientific Journal, Vol 13, No. 1, 105-110 p. ISSN 1337-2955.

Morgan, T., Veloutsou, A.C. (2013) Beyond technology acceptance: Brand relationships and online brand experience. In Journal of Business Research, Elsevier. Vol 66, pages 21-27. DOI: <10.1016/j.jbusres.2011.07.019>.

Palenčíková, Z. (2015) Produkty cestovného ruchu. Nitra: Fakulta stredoeurópskych štúdií, 102 s. ISBN 978-80-5580963-2.

Park, D.-B., Yoon, Y.-S. (2009) Segmentation by motivation in rural tourism: A Korean case study. In Tourism Management, Vol. 30, Is. 1: 99-108. DOI: 〈https://doi.org/10.1016/j.tourman.2008.03.011〉.

Pender, L., Sharpley, R. (2005) The management of Tourism. [online]. London: SAGE Publications, Ltd, 347 p. ISBN 0761940227. [cit. 2018-10-15]. DOI: <https://www.slideshare.net/vinodkalannavar/management-oftourism>.

Perri, A. (2015) Social Networking Usage: Recommended citation 2005-2015.” Pew Research Center. October2015. DOI: <http://www.pewinternet.org/2015/10/08/2015/Social-Networking-Usage-2005-2015/>.

Přikrylová, J., Jahodová, H. (2010) Moderní marketingová komunikace. Praha: Grada Publishing, 320 s. ISBN 978-80247-3622-8.

Rašovská, I., Ryglová, K. (2017) Management kvality služeb v cestovním ruchu: jak zvýšit kvalitu služeb a spokojenost zákazníkủ. Praha: Grada Publishing, 192 s. ISBN 978-80-247-5021-7.

Reime, M. - Hawkins, C. (1979) Tourism Development: A model for growth [online]. In Cornell and Restaurant Administration Quarterly, roč. 20, č. 1, p. 67-74. [cit. 2018-10-15]. DOI: 〈https://www.cabdirect.org/>.

Russell, R. \& Faulkner, B. (2004). Entrepreneurship, chaos and the tourism area lifecycle Annals of Tourism Research, 31(3), 556-579. Dostupné z <https://doi.org/10.1016/j.annals.2004.01.008>.

Salvatore, R., Chiodo, E., Fantini, A., (2018) Tourism transition in peripheral rural areas. Theories, issures and strategies. Annals of Tourism Research. vol. 68(C), pp. 41-51. DOI: <10.1016/j.annals.2017.11.003>.

Saxena,, G. (2016). Marketing Rural Tourism: USA: Edvard Elgan. 2016. eISBN: 978-1-78471-088-0.

Seaton, A. V., Bennett, M. M. (1996) The Marketing of Tourism Products: Concepts, Issues and Cases. London: International Thomson Business Press, 535 p. ISBN 1-86152-302-5.

Scheuch, F. (1993) Marketing. 4. vyd. Verlag Franz Vahlen, München, 1993, 635 s. ISBN 978-38-0061-735-7. 
Škarabelová, S. Marketingová komunikace ve veřejné správě. [online]. Pardubice: Univerzita Pardubice. [cit. 2018-1015]. DOI: 〈https://docplayer.cz/5759251-Marketingova-komunikace-ve-verejne-sprave.html>.

Štefko, R., Királová, A., Mudrík, M. (2015) Strategic Marketing Communication in Pilgrimage Tourism. Procedia Social and Behavioral Sciences, Vol. 175, 423-430 p. DOI: 〈https://doi.org/10.1016/j.sbspro.2015.01.1219>.

Van Vliet, V. (2012) Five product levels by Phillip Kotler. [online]. [cit. 2017-11-15]. DOI: https: $</ /$ www.toolshero.com/marketing/five-product-levels-kotler/>.

Xu, J.B., (2010) Percpetions of tourism products. In Tourism Management, vol. 31, no. 5, pp. 607-610. ISSN 02615177. DOI <https://doi.org/10.1016/j.tourman.2009.06.011>.

Yin, M. \& Jahanshahi, A.A. (2018) Rozvíjanie zdrojov založených na vedomostiach: úloha vel'kosti sociálnych sietí a dôvery spoločnosti podnikatel'ov. Sustainability, 10(10).

Zamazalová, M. (2009) Marketing obchodní firmy. Praha: Grada Publishing, a.s., 240 s. ISBN 978-80-247-2049-4. 